\title{
Recent Insights into the Biology of Hodgkin's Lymphoma
}

\author{
Diponkar Banerjee \\ Department of Pathology and Laboratory Medicine, British Columbia Cancer Agency, \\ Canada
}

\section{Introduction}

Hodgkin's lymphoma (HL) is currently recognized as B cell derived lymphoma with histological and biomarker-based distinction from other types of B cell derived lymphoma (Swerdlow, S.H. et al., 2008). HL had a worldwide incidence of 67,887 cases in 2008, with an age standardized rate of 1.0 per 100,000 (both genders) (http://globocan.iarc.fr/). Some of the information in this chapter has already been part of an earlier review article (Banerjee, D., 2011) and is cited again for the sake of completeness, but this chapter also provides some historical or current data that was not included that review.

\section{Historical aspects of Hodgkin's Lymphoma}

The earliest description of Hodgkin's lymphoma (HL) in an autopsy patient is attributed to Malpighi who described an 18 year old female with prominent splenic nodules in his 1666 publication (Malpighi, M., 1666). Thomas Hodgkin, whose name is now associated with this disease, was very careful to mention this fact in the published version of his paper "On some morbid appearances of the absorbent glands and spleen" (Hodgkin, T., 1832) read to the Royal Medical and Chirurgical Society of London on January $10^{\text {th }}$ and $24^{\text {th }}, 1832$. The paper was read not by Hodgkin but by the Society secretary Robert Lee. This was because Hodgkin was not a member of the Society at the time and therefore was prohibited from presenting the paper in person or even being present in the room during Lee's reading of his paper.

Although the compound microscope had been invented in 1590 by spectacle-makers Zacharias Janssen and his son Hans (Uluç, K. et al., 2009), its use in pathology was non existent in Malpighi's time. It is thus impossible to verify that Malpighi had indeed described what we now recognize as Hodgkin's lymphoma. Even Hodgkin, who actually knew about light microscopy, having used it in a study published with Lister (Hodgkin, T. \& Lister, J.J., 1827), did not use a microscope to study this disease. This is due to the fact that tissue processing, staining, and histopathology were not established techniques at the time. Two of Hodgkin's original 7 cases were subsequently proven to be true examples of Hodgkin's lymphoma by Fox (Fox, H., 1926) and again by Poston, this time demonstrating that the neoplastic cells indeed expressed CD15 (Poston, R.N., 1999). Case IV is likely to be an example of a peripheral T cell lymphoma with rare CD15+ Reed Sternberg-like cells. It is possible the other 4 cases were also HL but no tissue was available for histology or immunohistochemistry at the time of Poston's study. 
Hodgkin's description of his 7 cases remained in obscurity for years even after being rediscovered and attributed to him by Bright (Bright, R., 1838) and Wilks (Wilks, S., 1856). It was through Wilks' persistence that the disease was later recognized as Hodgkin's disease (Wilks, S., 1859). Wilks had to put the term "Hodgkin's disease" in the title of his paper to make the point (Wilks, S., 1865).

Most of the cases that Hodgkin described were patients who died soon after admission to hospital with terminal disease. He did have an opportunity to treat one of the 7 patients with cascarilla and soda to "improve his general health" and iodine "as an agent most likely to affect the glands" but noted dryly in his report that the treatment "appeared to be productive of no advantage, on which account it is probable the patient withdrew himself from my observation" (Hodgkin, T., 1832).

The first description of the histopathological features of HL was published by Theodor Langhans, (Langhans, T., 1872). Six years later, Greenfield published the histopathological features of HL in the English language (Greenfield, W., 1878). The detailed description of the characteristic multinucleated cells in this disease was described by Carl Sternberg (Sternberg, C., 1898) and Dorothy Reed (Reed, D., 1902) and are now called Reed-Sternberg cells. Gall and Mallory established HL as a neoplastic process (Gall, E. \& Mallory, T., 1942). The first definitive evidence of the neoplastic nature of HL came in 1967 with the publication about the cytogenetics of HL (Seif, G.S. \& Spriggs, A.I., 1967), further supported by a 1975 publication that showed clonal growth of Hodgkin cells (Boecker, W.R. et al., 1975).

The histopathological classification of HL has undergone several changes over the years. The first attempt to classify HL was by Jackson and Parker who in 1947 proposed three categories - paragranuloma, granuloma and sarcoma subtypes (Jackson, H. \& Parker, F., 1947). Smetana and Cohen published the results of a retrospective review of mortality rates of HL cases culled from the records of the Armed Forces Institute of Pathology, classified according to the Jackson and Parker classification (Smetana, H.F. \& Cohen, B.M., 1956). They did not describe how these patients had been treated.

Further refinement of HL classification came with the publications of Lukes and Butler (Lukes, R.J. et al., 1966; Lukes, R.J. \& Butler, J.J., 1966), who divided HL into 6 groups: lymphocytic and/or histiocytic, (L \& H), nodular, lymphocytic and/or histiocytic (L \& H), diffuse, nodular sclerosis (NS), mixed, diffuse fibrosis and reticular. This was later simplified at the Rye Conference into 4 categories: Lymphocyte predominance (LP), Nodular sclerosis (NS), Mixed cellularity (MC), and Lymphocytic depletion (LD) (Lukes, R. et al., 1966). The first system to separate nodular lymphocyte predominance from classical HL was published in 1994 as part of the Revised European-American lymphoma (REAL) classification system, including the addition of a provisional entity of lymphocyte-rich classical HL (Harris, N.L. et al., 1994). The 2001 and 2008 WHO classification systems accepted the new category which is no longer a provisional one (Jaffe, E.S. et al., 2001; Swerdlow, S.H. et al., 2008). Recently, a comprehensive update of the histopathology and immunohistochemistry findings in HL has been published (Eberle, F.C. et al., 2009).

The therapy of HL has also undergone numerous changes, starting with Thomas Hodgkin's attempts with cascarilla and soda and iodine combination therapy on one patient (Hodgkin, T., 1832). Fowler's solution (potassium arsenite), a panacea concocted in 1786 by Thomas Fowler (Sears, D.A., 1988) for all sorts of chronic conditions, was used to treat HL (Waxman, S. \& Anderson, K.C., 2001). It turns out that this was effective. In 1937 Hendrick and Burton 
from the University of Toronto published a case report of a young male patient with HL who had a remarkable response to colloidal arsenic (Hendrick, A.C. \& Burton, E.F., 1937). More recently, Mathas et al. have shown that sodium arsenite rapidly down regulates constitutive IKB kinase (IKK) as well as NF-KB activity and induces apoptosis in Hodgkin Reed-Sternberg (HRS) cell lines containing functional IKB proteins and that arsenic trioxide induces tumour reduction in xenograft models of HL (Mathas, S. et al., 2003). The use of nitrogen mustard for the chemotherapy of HL was introduced by in 1946 (Goodman, L.S. et al., 1946), with reports from others on the results of nitrogen mustard on HL in the forties (Alpert, L.K. \& Peterson, S.S., 1947; Dameshek, W. et al., 1949).

Immunotherapy was attempted in 1928 (Wallhauser, A. \& Whitehead, J.M., 1928). Three HL patients were treated with saline extracts from affected lymph nodes by subcutaneous injections. Two of the 3 patients achieved complete remission, while the third relapsed after initial response, but responded to a second round of injections. This report encouraged Hanrahan to try the same approach in 1930 with 9 patients but with less spectacular results (Hanrahan, E.M., 1930). Hanrahan used a preservative, tricresol (a mixture of three isomeric phenols derived from toluene: ortho-, meta- or para-methylphenol), in the extract, so one could speculate that whatever the active substance was in the HL tissue extract might have been damaged by tricresol.

Radiotherapy for HL was reported in 1932 (Chevalier, P. \& Bernard, J., 1932) and firmly established as an effective therapeutic modality by Vera Peters of the Ontario Cancer Institute (Peters, M.V., 1960, 1965, 1966; Peters, M.V. \& Middlemiss, K.C., 1958).

Modern therapy of HL has been described in recent reviews (Boleti, E. \& Mead, G.M., 2007; Edwards-Bennett, S.M. et al., 2010; Eichenauer, D.A. et al., 2009; Federico, M. et al., 2009; Mendler, J.H. et al., 2008; Oflazoglu, E. et al., 2008) and not further discussed here.

\section{The cell of origin and the pathobiology of HRS cells}

The neoplastic cells of classical HL (cHL) (Hodgkin/Reed-Sternberg cells or HRS cells) are usually derived from germinal centre B cells, and rarely are of T cell origin; those of nodular lymphocyte predominance (NLPHL) HL (LP cells) cases are always of germinal centre B cell origin (Brauninger, A. et al., 2006; Caporaso, N.E. et al., 2009; Kuppers, R., 2009; Küppers, R., 2009; Kuppers, R. et al., 2002; Mani, H. \& Jaffe, E.S., 2009; Marafioti, T. et al., 2000; Seitz, V. et al., 2000).

Despite the fact that cHL HRS cells are derived from germinal centre or post-germinal centre B cells, they lack B cell markers including the B cell receptor (BCR) (Schwering, I. et al., 2003) as they lose their B cell programming (Hertel, C.B. et al., 2002) through several mechanisms including promoter DNA methylation (Doerr, J.R. et al., 2005; Ushmorov, A. et al., 2006), inhibition of transcription factor E2A by HLH proteins ABF-1 and Id2 resulting in reprogramming of neoplastic B cells (Mathas, S. et al., 2006), loss of PU.1 expression associated with defective immunoglobulin gene transcription (Jundt, F. et al., 2002), downregulation of BOB.1/OBF.1 and Oct2 (Stein, H. et al., 2001) and upregulation of NOTCH1, a negative regulator of the B cell program (Jundt, F. et al., 2008). At the same time non-B cell lineage proteins are upregulated (Atayar, C. et al., 2005; Dorfman, D.M. et al., 2005).

The LP cells in NLPHL are derived from antigen-activated germinal centre $\mathrm{B}$ cells (Braeuninger, A. et al., 1997), express functional $\mathrm{IgV}$ genes with intraclonal diversification 
(Mottok, A. et al., 2005; Schmitz, R. et al., 2009), BCL6 protein (Falini, B. et al., 1996), and GCET1 (centerin), a germinal centre B cell associated serpin (Montes-Moreno, S. et al., 2008). In contrast to H/RS cells, LP cells retain most of their B cell programming; however, LP cells also show selective loss of the B cell phenotype such as down regulation of CD19, CD37, PAG and LCK (Dogan, A. et al., 2000; Masir, N. et al., 2006; Tedoldi, S. et al., 2007). The mechanism is not related to promoter methylation of the encoding genes (Tedoldi, S. et al., 2007).

\subsection{The role of the Epstein Barr virus in HL}

The Epstein-Barr virus was first identified in 1964 by Epstein, Achong and Barr (Epstein, M. et al., 1964). Up to $40-60 \%$ of cHL cases may contain the EBV genome (Kapatai, G. \& Murray, P., 2007), but since EBV infects $90 \%$ of the adult population worldwide (Cohen, J., 2000), and is a B lymphocytotropic virus, it may be a passenger, but not a driver in HL.

Comprehensive EBV-human protein interaction maps have been generated by Calderwood et al. (Calderwood, M.A. et al., 2007) who showed over 40 interactions between EBV proteins and over 170 interactions between EBV and human proteins.

\section{Genetic defects in primary immunodeficiency disorders (PID) and HL}

Mutations in the SH2D1A and ITK genes are associated with aberrant T and NK function that predisposes patients to serious EBV infections, and lymphoproliferative disease including $\mathrm{HL}$ in those that survive the initial fulminant infectious mononucleosis. Detailed reviews of these PIDs has been published recently (Rezaei, N., Hedayat, M., et al., 2011; Rezaei, N., Mahmoudi, E., et al., 2011) and some key points are summarized below.

\subsection{SH2D1A}

The small (128-amino acid) Src homology 2 domain protein 1A (SH2D1A, DSHP or SAP) is associated with X-linked lymphoproliferative disease (XLP). The patients respond to the Epstein-Barr virus (EBV) infection with a fulminant, frequently fatal infectious mononucleosis syndrome (Purtilo, D.T. et al., 1975; Rezaei, N., Mahmoudi, E., et al., 2011). Most cases of XLP are due to mutations in the SH2D1A gene, which codes for the adaptor molecule called Signaling Lymphocytic Activation Molecule (SLAM; CD150)-associated protein (SAP) (Rezaei, N., Mahmoudi, E., et al., 2011). Patients with XLP and Sap null mice have defective natural killer and CD8+ $\mathrm{T}$ cell cytotoxicity, impairment of $\mathrm{T}$ cell cytokine production, activation-induced cell death, germinal centre formation and $\mathrm{T}$ NK cell development (Rezaei, N., Mahmoudi, E., et al., 2011). Survivors may develop agammaglobulinemia and B cell malignant lymphomas including HL (Rezaei, N., Hedayat, M., et al., 2011; Seemayer, T.A. et al., 1995). SH2D1A has been detected in 5 of $6 \mathrm{EBV}$ negative classical HL cell lines including T cell derived HL cell lines (Kis, L.L. et al., 2003) and SH2D1A mRNA found in HRS cells in HL tissue (Nichols, K.E. et al., 1998). The lack of EBV in HL cell lines expressing SH2D1A protein is unexplained (Kis, L.L. et al., 2003).

\subsection{IL-2-inducible T-cell kinase (ITK)}

IL-2-inducible T-cell kinase (ITK) is a cytoplasmic non-receptor tyrosine kinase expressed in thymocytes, mature T cells, NK cells, iNKT cells, and mast cells (Au-Yeung, B.B. \& Fowell, D.J., 2007; Au-Yeung, B.B. et al., 2006; Gadue, P. \& Stein, P.L., 2002; Gomez-Rodriguez, J. et al., 
2007; Grasis, J.A. et al., 2003; Iyer, A.S. \& August, A., 2008; Qi, Q. et al., 2011). ITK mutations lead to fatal EBV induced lymphoproliferative disease characterized as hemophagocytic lymphohistiocytosis (HLH) and HL (Huck, K. et al., 2009; Stepensky, P. et al., 2011).

\section{Prognostic indicators derived from transcriptome, genome and host response patterns}

\subsection{Gene copy number variation in HRS cells}

Complex chromosomal and genomic alterations occur in HRS cells of HL. My laboratory reported novel gains and losses of 9 novel regions in Hodgkin Lymphoma cell lines L428 and KMH2, which shared gains in chromosome cytobands 2q23.1-q24.2, 7q32.2-q36.3, 9p21.3-p13.3, 12q13.13-q14.1, and losses in 13q12.13-q12.3, and 18q21.32-q23. The genes located in these regions include cell cycle associated genes, MAPK signaling pathway genes, those encoding tight junction proteins, Jak/Stat signaling pathway genes and tumour suppressor gene ING3 (Fadlelmola, F. et al., 2008).

Steidl et al. compared patients that had failed primary treatment with those that responded as usual (Steidl, C., Telenius, A., et al., 2010). Gains of 16p11.2-13.3 were associated with treatment failure and shorter disease-specific survival. One of the genes mapping to this region is the multidrug resistance gene ABCC1 encoding multidrug resistance protein MRP1 (Leslie, E. et al., 2001; Rosenberg, M. et al., 2001), and functional studies indicate that this does play a role in chemoresistance (Steidl, C., Telenius, A., et al., 2010).

\subsection{Gene expression studies}

Devilard et al. using whole cells including the microenvironment, found a signature that can distinguish between good outcome Hodgkin's disease and bad outcome cases (Devilard, E. et al., 2002). Good outcome was associated with overexpression of genes involved in apoptotic induction and cell signaling pathways, including cytokines, whereas bad outcome was associated with overexpression of genes associated with fibroblast activation, angiogenesis, extracellular matrix remodeling, cell proliferation, and the down regulation of tumor suppressor genes.

Sánchez-Aguilera et al. identified 145 genes predictive of outcome (Sanchez-Aguilera, A. et al., 2006). Four different signatures were obtained by supervised hierarchical clustering, 2 of which were associated with the host immune response of tumor microenvironment and the other 2 with the HRS cells based on known expression in HL cell lines and normal germinal centre B cells.

Chetaille et al. studied $63 \mathrm{cHL}$ cases (not enriched for HRS by microdissection, thus including cells from the microenvironment) using full transcriptome coverage and found 47 genes associated with adverse outcome, and 403 genes associated with favorable outcome (Chetaille, B. et al., 2009). Favorable outcome was associated with expressed genes of the "Bcell" cluster, whereas genes associated with unfavorable outcome were in the "extracellular matrix" cluster.

Global gene expression analysis of microdissected LP cells (L\&H cells) from 5 cases of NLPHL has been reported by Brune et al. (Brune, V. et al., 2008). The gene expression 
signatures were closer to T cell-rich B cell lymphoma and classical HL than to diffuse large B cell lymphoma, Burkitt lymphoma, and follicular lymphoma. There is increased expression of ABCC1 in LP cells, which as already discussed, encodes multidrug resistance protein MRP1 (Leslie, E. et al., 2001) and is also amplified and overexpressed in primary treatment refractory cHL (Steidl, C., Telenius, A., et al., 2010).

\subsection{Host microenvironment/immune response}

An increased number of CD68+ macrophages is associated with a shortened progressionfree survival, an increased risk of relapse after HDCT/ASCT, and shortened disease-specific survival. In multivariate analysis, CD68+ cells as a prognostic factor is superior to the International Prognostic Score for disease-specific survival. The absence of an increased number of CD68+ cells in patients with limited-stage disease predicted long-term diseasespecific survival of $100 \%$ in cHL patients treated with current treatment protocols (Steidl, C., Lee, T., et al., 2010). The immunohistochemistry (IHC) assay for CD68, which is widely available in clinical laboratories, can identify patients with HL who are likely to be refractory to first line therapy and was noted to be the first predictive in-vitro test for cHL (DeVita, V.T., Jr. \& Costa, J., 2010).

\subsection{Mechanisms of chemoresistance}

The multidrug resistance gene ABCC1 in overexpressed in LP and HRS cells and HRS cells contain increased copy number of the ABCC1 gene (Brune, V. et al., 2008; Steidl, C., Telenius, A., et al., 2010). HL tumor samples contain a population of cells that increase efflux of Hoechst 33342 dye and are resistant to gemcitabine, a commonly used drug for the treatment of refractory HL. These cells have the phenotype of HRS cells and express multidrug resistance genes ABCG2 and MDR1 (ABCB1) (Shafer, J.A. et al., 2010).

Genes encoding cytokine receptors (IL5RA, IL13RA1), markers expressed on antigenpresenting cells (CD40, CD80), as well as genes with known association to chemoresistance, such as myristoylated alanine-rich protein kinase C substrate, and PRAME (preferentially expressed antigen in melanoma) are upregulated in chemoresistant cells (Staege, M.S. et al., 2008).

Chemoresistance in HL is also related to XIAP (X-linked inhibitor of apoptosis) an NFkappaB-independent target of bortezomib. Bortezomib sensitizes HL cells against a variety of cytotoxic drugs independent of NF-kappaB (Kashkar, H. et al., 2007).

\section{How the HRS cell, an abnormal B cell clone, survives the normal apoptotic process and immune destruction}

Normally B cells that fail to achieve productive or high affinity Ig gene rearrangements or lack BCR are destroyed during the germinal centre reaction (Gordon, J. et al., 1993; GuzmanRojas, L. et al., 2002; Hollowood, K. \& Goodlad, J.R., 1998; Zhang, Q.P. et al., 2005). There are several excellent reviews on the topic of the germinal centre reaction and mechanisms of $B$ cell apoptosis and survival during a normal antigen driven reaction (Elgueta, R. et al., 2010; Goodnow, C.C. et al., 2010; Nutt, S.L. \& Tarlinton, D.M., 2011; Oracki, S.A. et al., 2010; 
Vikstrom, I. \& Tarlinton, D.M., 2011; Vinuesa, C.G. et al., 2010), so only a brief summary is provided in this chapter.

\subsection{The germinal center reaction}

The biologic or physiologic purpose of the germinal centre reaction is to generate long-term humoral immunity in the adaptive immune system against antigens expressed by pathogens, while, at the same time, eliminating autoreactive clones. The end result is the generation of long-lived antibody-secreting plasma cells and memory B cells which can rapidly trigger subsequent waves of plasma cell production when the same antigen/s are encountered again. The germinal centre reaction is a complex cascade of events, highly regulated, requiring crosstalk and collaboration between B cells, follicular helper T cells and antigen presenting cells including dendritic cells, macrophages and follicular dendritic cells (Cattoretti, G. et al., 2005; Elgueta, R. et al., 2010; Guzman-Rojas, L. et al., 2002; Jardin, F. et al., 2007; Kosco-Vilbois, M.H., 2003; Park, C.S. \& Choi, Y.S., 2005; Phan, R.T. \& Dalla-Favera, R., 2004; Schenka, A.A. et al., 2005; Siepmann, K. et al., 2001; Spender, L.C. et al., 2009; Tarlinton, D.M. \& Smith, K.G., 2000; Zhang, Q.P. et al., 2005).

\subsection{The primary lymphoid follicle}

Primary lymphoid follicles appear in the second trimester of fetal life in humans and are composed of antigen-naive recirculating B cells that migrate through meshworks of follicular dendritic cells (FDC) with a transit time of 24 hours (Howard, J.C. et al., 1972). These antigen-naive B cells have already undergone recombination of gene fragments, with a theoretical repertoire of $>10^{10}$ antigen binding receptors (Berek, C. \& Milstein, C., 1988). When these $B$ cells encounter an antigen, they increase their expression of the chemokine receptor CCR7 which facilitates their migration to the interface between $\mathrm{T}$ and $\mathrm{B}$ cells zones (Cyster, J.G., 2005; Okada, T. \& Cyster, J.G., 2006). Here they can contact antigen-primed T cells, triggering a burst of proliferation of the activated B cells in the outer follicle, ultimately forming a germinal centre (Coffey, F. et al., 2009). HRS cells of cHL also express CCR7 which may explain why HRS cells tend to be located in interfollicular zones (Höpken, U.E. et al., 2002). LP cells are CCR7- and therefore remain in germinal centers.

\subsection{Somatic hypermutation - Generation of higher affinity antibodies}

Activated B cells undergo a process of affinity maturation in the germinal center reaction. Rearranged immunoglobulin (Ig) variable region genes undergo random point mutations by a process called somatic hypermutation (SHM) in which single nucleotide substitutions are introduced at a rate of one mutation per 1000 base pairs per generation (Berek, C. \& Milstein, C., 1988). Both LP cells of NLPHL and HRS cells of cHL show evidence of SHM of Ig variable region genes (Liso, A. et al., 2006) and are therefore considered to be derived from antigen-activated $B$ cells.

\subsection{Selection of high affinity $B$ cells}

Since SHM is a random process, a wide range of antigen-binding affinities may result. A mechanism for ensuring that high affinity antigen receptor positive cells are preferentially 
selected is required for optimal function. The default event seems to be death by apoptosis through the Fas/CD95 pathway unless the cells are rescued by signals from other cell types. Fas/CD95 triggers elimination of low-affinity and self-reactive B cell clones that arise during the germinal centre reaction through apoptosis (Defrance, T. et al., 2002). Prior to apoptosis, rapid activation of caspase-8 occurs in association with CD95 death-inducing signaling complex (DISC). c-FLIP(L), which protects B cells from Fas/CD95 triggered apoptosis is rapidly lost from the CD95 DISC unless the $\mathrm{B}$ cells are exposed to the survival signal provided by CD40L from follicular T helper cells (Hennino, A. et al., 2001). In cHL, over $80 \%$ of cases show constitutive expression of c-FLIP which protects the HRS cells from Fas/CD95 triggered apoptosis without the need for CD40L survival signals (Mathas, S. et al., 2004; Thomas, R. et al., 2002; Uherova, P. et al., 2004).

\subsection{The role of the follicular helper $\mathrm{T}$ cell $\left(\mathrm{T}_{\mathrm{FH}}\right)$}

The localization of $\mathrm{T}$ cells coexpressing HNK-1 (CD57) in the germinal centers (GC) of lymph nodes and spleens was reported by my laboratory (Banerjee, D. \& Thibert, R.F., 1983). Although expressing HNK-1 (CD57), which was initially thought to be human natural killer cell specific, these cells were not cytotoxically active. Under certain circumstances, we found that these cells could either suppress or enhance immunoglobulin production by pokeweed mitogen-activated tonsillar B cells (Banerjee, D. et al., 1988). Such cells are now recognized to be specialized $\mathrm{CD} 4+\mathrm{T}$ cells called follicular helper $\mathrm{T}$ cells $\left(\mathrm{T}_{\mathrm{FH}}\right)$ that home to the germinal center and play a pivotal role in regulating the fate of $\mathrm{B}$ cell in the germinal centre reaction. They express cell surface antigens CD4, CD57, and CXCR5, produce IL-21, IL-6, IL-27, BCL-6, ICOS, CD40L, and PD-1 (Crotty, S., 2011). While germinal centre CD57+ CD4+ $\mathrm{T}$ cells have been shown to be a major T helper cell subset for GC-B cells in Ig synthesis, and have the capacity to induce activation-induced cytosine deaminase (AID) and class switch recombination (Kim, J.R. et al., 2005), the most effective subset of capable of inducing IgG production is the CXCR5hi ICOShi CD4+ T cell. The presence or absence of CD57 does not appear to affect this function (Rasheed, A.U. et al., 2006).

Cells with the phenotype of $\mathrm{T}_{\mathrm{FH}}$ are usually found in contact with of NLPHL LP cells (NamCha, S.H. et al., 2009) forming characteristic rosettes. The expression of PD-1 is more frequent than that of CD57 by the T cell rosettes around LP cells (Churchill, H.R. et al., 2010). PD-1+ T cells are also reported in cHL and HRS cells express both ligands for PD-1 (CD279), B7-H1 (PDL1; CD274) and B7-DC (PDL2; CD273) (Yamamoto, R. et al., 2008). The function of PD-1+ T cells in HL is unknown. In normal germinal center reactions, PD-1 signals enhance B cell survival (Good-Jacobson, K.L. et al., 2010), thus it is possible that PD-1+ $\mathrm{T}_{\mathrm{FH}}$ cells in both NLPHL and cHL provide additional survival signals. Another protective effect of PD-1 could be mediated through its inhibition of cytotoxic T cells via overexpressed PD-1 ligands CD273 or CD274 by the target cells of cytotoxic T cells (Norde, W.J. et al., 2011).

\subsection{IL-21}

HRS cells aberrantly express IL-21 and the IL-21 receptor. IL-21 activates STAT3 in HRS cells, up-regulates STAT3 target genes, and protects HRS cells from CD95 death receptorinduced apoptosis. In addition, IL-21 through up-regulation of the CC chemokine macrophage-inflammatory protein-3a (MIP-3a) attracts CCR6+CD4+CD25+FoxP3+CD127 lo regulatory $\mathrm{T}$ cells to migrate close to the proximity of HRS cells, protecting them from immune attack (Lamprecht, B. et al., 2008). 


\subsection{IL-6}

IL-6 is a pleiotropic cytokine (also called B-cell stimulatory factor-2, IFN-b2, 26-kDa protein, Hybridoma/plasmacytoma growth factor and hepatocyte stimulating factor HSF) with biological activities in immune regulation, hematopoiesis, inflammation and neoplasia (Kishimoto, T., 2010). HL cells express multiple cytokines, including interleukin-6 (IL-6) (Tesch, H. et al., 1992). Increased serum levels are associated with advanced disease and worse prognostic scores (Vener, C. et al., 2000). HL cells produce IL-6 through constitutional activation of the PI3K signaling pathway which promotes expression of HLXB9, an EHG homeobox gene family member, which in turn activates IL6 (Nagel, S. et al., 2005). Thus HL cells, and presumably HRS cells in vivo, do not solely depend upon $\mathrm{T}_{\mathrm{FH}}$ for IL-6 supply but make their own, possibly benefiting from an autocrine loop.

\subsection{BCL-6}

The BCL6 proto-oncogene encodes a nuclear transcriptional repressor. It is important in germinal center (GC) formation and regulates lymphocyte function, differentiation, and survival. BCL-6 suppresses p53 in GC B-cells and protects B-cell lines from apoptosis induced by DNA damage. BCL-6 is thought to allow GC B-cells to sustain the low levels of physiological DNA breaks related to somatic mutation (SM) and immunoglobulin class switch recombination (Jardin, F. et al., 2007). BCL-6 is also an important regulator of the $T_{\mathrm{FH}}$ cell program, being essential for CXCR5 expression and follicular homing by $\mathrm{T}_{\mathrm{FH}}$ cells $(\mathrm{Yu}$, D. et al., 2009).

BCL-6 expression is usually seen in NLPHL and about $30 \%$ of lymphocyte rich classical HL (LRCHL) but not other forms of cHL (Nam-Cha, S.H. et al., 2009). However, in another study, none of the cases of LRCHL expressed BCL-6 (Brauninger, A. et al., 2003).

\subsection{Bfl-1}

$\mathrm{Bfl}-1$ is a NF-kB target gene from the Bcl-2 family of apoptosis-regulating proteins. Bfl-1 is expressed in HRS cells in clinical biopsies and also expressed in HL cell lines. Bfl-1 can protect cultured $\mathrm{H} / \mathrm{RS}$ cells from apoptosis induced by pharmacological inhibitors of NF-kB (Hinz, M. et al., 2001; Loughran, S.T. et al., 2011).

\section{Next generation whole genome sequencing and new insights into the pathobiology of HL}

Technological improvements now allow the analysis of entire genomes and transcriptomes at a sufficient resolution to detect point mutations at high speed and reduced cost (Cronin, M. \& Ross, J.S., 2011). Two recent discoveries that are relevant to HL are highlighted in this review.

\subsection{MHC class II transactivator CIITA, PD-1 and PD-1 ligands}

In $15 \%$ of $\mathrm{cHL}$, a gene fusion involving the major histocompatibility complex (MHC) class II transactivator CIITA (MHC2TA) and several partners has been reported (Steidl, C. et al., 2011). Not only is one of the fusions (with an uncharacterized gene BX648577) associated 
with downregulation of HLA Class II expression which could help HRS cells evade immunosurveillance, CIITA also fuses with genes encoding CD274 (PDL1) and CD273 (PDL2), leading to overexpression of both these PD-1 ligands by HRS cells. This could have two beneficial effects on HRS cell survival, the first through PD-1 survival signals from $T_{\mathrm{FH}}$ cells to the neoplastic B cells and the second through inhibition of cytotoxic $\mathrm{T}$ cells as already discussed above.

\subsection{EZH2}

Mutations in EZH2, a polycomb group oncogene which encodes a histone methyltransferase, have been described in follicular lymphomas and diffuse large B cell lymphomas of germinal centre type. These mutations involve a single tyrosine (Y641) in the SET domain of the EZH2 protein reducing its enzyme action (Morin, R.D. et al., 2010). While HL cases were not included in this study, this protein may have a role in HL. Whereas the expression of the polycomb group gene encoded proteins BMI-1 and EZH2 genes is associated with resting or proliferating germinal centre B cells, respectively and not coexpressed, Hodgkin/Reed-Sternberg (H/RS) cells co-express BMI-1 and EZH2 (Dukers, D.F. et al., 2004; Raaphorst, F.M. et al., 2000).

\section{New targets for potential therapeutic approaches}

CD20, a B cell expressed phosphoprotein, is usually expressed by LP cells in NLPHL but variably positive in a minority of cHL cases as recently reviewed by Saini and others (Saini, K.S. et al., 2011). Despite CD20 negativity in most cases of cHL, patients refractory to all conventional HL therapies have responded to rituximab (Younes, A. et al., 2003). An excellent review of the myriad of potential targets for novel therapies for treatment refractory HL has been published by Younes (Younes, A., 2009), and some of these, and the rationale for their use have been summarized in one of my recent review articles (Banerjee, D., 2011).

My laboratory recently reported that a $21 \mathrm{kDa}$ protein (Zhou, M. et al., 2008), which we subsequently identified as CYB5B, an outer mitochondrial membrane protein, is overexpressed in the cytoplasm and plasma membrane of HRS cells but not at the plasma membrane of normal reactive lymphocytes or bone marrow precursor cells (Murphy, D. et al., 2010). Gains in the CYB5B locus in HL cell lines KMH2 and L428 were detected. HL cell lines show increased CYB5B mRNA but reactive lymphocytes and bone marrow precursor cells show no increase in CYB5B mRNA in comparison to housekeeping genes. Due to its location at the plasma membrane of only neoplastic cells in CHL, diffuse large B cell lymphoma (DLBCL) and anaplastic large cell lymphoma (ALCL), CYB5B might be an attractive target for antibody based therapy as toxicity should be minimal since we have determined that normal, reactive lymphocytes and CD34+ bone marrow precursor cells do not express the protein at the plasma membrane (Murphy, D. et al., 2010). We are in the process of creating chimeric antibodies to determine whether they are effective in killing HRS cells in pre-clinical models.

\section{Discussion}

From Hodgkin's first report in 1832 on what we now call Hodgkin's Lymphoma, to this day, the pathobiology of HL continues to intrigue and surprise us with the myriad ways in 
which the LP and HRS cells defy all physiologic rules of B cell survival by exploiting the very signals that would normally stop undesirable B cells from surviving. The vast network of crosstalk and redundancy of pathways the tumour cells have successfully utilized keeps growing in complexity. These observations challenge our preconceived notions of cell lineage fidelity as defined by expressed cell surface proteins and other biomarkers. Indeed reprogramming and plasticity of B cells is a reality, thus neoplastic B cells derived from the germinal centre can assume various "identities" and confuse regulatory cells and pathways (Mathas, S., 2007). Eventually, classification of B cell lymphomas including HL will require, not just lineage determination and morphology-based classification and grading, but also the detailed mapping of aberrant pathways in sufficient resolution for us to understand all the potential nodes that could be novel therapeutic targets.

\section{Conclusion}

HL is a unique set of B cell lymphomas that are characterized by the exploitation of redundant pathways, and crosstalk between regulatory cells that promote the growth and survival of defective B cells which, under normal conditions, would die during the germinal centre reaction. While this may seem an insurmountable level of complexity, the potential for effective novel targeted therapies to deal with refractory disease will be possible to attain when a comprehensive map of pathway pathology is feasible in the future.

\section{Acknowledgment}

This study was funded through operating grants from the Canadian Institutes of Health Research, other financial support from the Trudi Desmond Memorial Fund, the British Columbia Cancer Agency, the Department of Pathology and Laboratory Medicine, University of British Columbia Endowment Fund, the Lymphoma Foundation Canada, and the British Columbia Cancer Foundation.

\section{References}

Alpert, L. K. \& Peterson, S. S. (1947), "The use of nitrogen mustard in the treatment of lymphomata", Bull U S Army Med Dep, Vol. 7 No. 2, 187-194

Atayar, C., Poppema, S., Blokzijl, T., Harms, G., Boot, M. \& van den Berg, A. (2005), "Expression of the T-cell transcription factors, GATA-3 and T-bet, in the neoplastic cells of Hodgkin lymphomas", Am J Pathol, Vol. 166 No. 1, 127-134 0002-9440 (Print) 0002-9440 (Linking).

Au-Yeung, B. B. \& Fowell, D. J. (2007), "A key role for Itk in both IFN gamma and IL-4 production by NKT cells", J Immunol, Vol. 179 No. 1, 111-119 0022-1767 (Print) 00221767 (Linking).

Au-Yeung, B. B., Katzman, S. D. \& Fowell, D. J. (2006), "Cutting edge: Itk-dependent signals required for CD4+ T cells to exert, but not gain, Th2 effector function", J Immunol, Vol. 176 No. 7, 3895-3899 0022-1767 (Print) 0022-1767 (Linking).

Banerjee, D. (2011), "Recent Advances in the Pathobiology of Hodgkin's Lymphoma: Potential Impact on Diagnostic, Predictive, and Therapeutic Strategies", Adv Hematol, Vol. 2011, 439456 1687-9112 (Electronic). 
Banerjee, D., Baril, J., Bell, D. A., McFarlane, D. \& Karim, R. (1988), "Suppression of immunoglobulin production by germinal centre HNK-1+ CD3+ cells.", Adv Exp Med Biol, Vol. 237, 421-425 0065-2598.

Banerjee, D. \& Thibert, R. F. (1983), "Natural killer-like cells found in B-cell compartments of human lymphoid tissues.", Nature, Vol. 304 No. 5923, 270-272 0028-0836.

Berek, C. \& Milstein, C. (1988), "The dynamic nature of the antibody repertoire.", Immunol Rev, Vol. 105, 5-26 0105-2896.

Boecker, W. R., Hossfeld, D. K., Gallmeier, W. M. \& Schmidt, C. G. (1975), "Clonal growth of Hodgkin cells", Nature, Vol. 258 No. 5532, 235-236 0028-0836 (Print) 0028-0836 (Linking).

Boleti, E. \& Mead, G. M. (2007), "ABVD for Hodgkin's lymphoma: full-dose chemotherapy without dose reductions or growth factors", Ann Oncol, Vol. 18 No. 2, 376-380 09237534 (Print) 0923-7534 (Linking).

Braeuninger, A., Kuppers, R., Strickler, J. G., Wacker, H. H., Rajewsky, K. \& Hansmann, M. L. (1997), "Hodgkin and Reed-Sternberg cells in lymphocyte predominant Hodgkin disease represent clonal populations of germinal center-derived tumor B cells", Proc Natl Acad Sci U S A, Vol. 94 No. 17, 9337-9342 0027-8424 (Print) 0027-8424 (Linking).

Brauninger, A., Schmitz, R., Bechtel, D., Renne, C., Hansmann, M. L. \& Kuppers, R. (2006), "Molecular biology of Hodgkin's and Reed/Sternberg cells in Hodgkin's lymphoma", Int J Cancer, Vol. 118 No. 8, 1853-1861 0020-7136 (Print) 0020-7136 (Linking).

Brauninger, A., Wacker, H. H., Rajewsky, K., Kuppers, R. \& Hansmann, M. L. (2003), "Typing the histogenetic origin of the tumor cells of lymphocyte-rich classical Hodgkin's lymphoma in relation to tumor cells of classical and lymphocytepredominance Hodgkin's lymphoma", Cancer Res, Vol. 63 No. 7, 1644-1651 00085472 (Print) 0008-5472 (Linking).

Bright, R. (1838), "Observations on abdominal tumors and in tumescence: illustrated by cases of disease of the spleen. With remarks on the general pathology of that viscus.", Guy's Hosp. Rep., Vol. 3, 401-461

Brune, V., Tiacci, E., Pfeil, I., Doring, C., Eckerle, S., van Noesel, C. J., Klapper, W., Falini, B., von Heydebreck, A., Metzler, D., Brauninger, A., Hansmann, M. L. \& Kuppers, R. (2008), "Origin and pathogenesis of nodular lymphocyte-predominant Hodgkin lymphoma as revealed by global gene expression analysis", J Exp Med, Vol. 205 No. 10, 2251-2268 1540-9538 (Electronic) 0022-1007 (Linking).

Calderwood, M. A., Venkatesan, K., Xing, L., Chase, M. R., Vazquez, A., Holthaus, A. M., Ewence, A. E., Li, N., Hirozane-Kishikawa, T., Hill, D. E., Vidal, M., Kieff, E. \& Johannsen, E. (2007), "Epstein-Barr virus and virus human protein interaction maps", Proc Natl Acad Sci U S A, Vol. 104 No. 18, 7606-7611 0027-8424 (Print) 00278424 (Linking).

Caporaso, N. E., Goldin, L. R., Anderson, W. F. \& Landgren, O. (2009), "Current insight on trends, causes, and mechanisms of Hodgkin's lymphoma", Cancer J, Vol. 15 No. 2, 117-123 1528-9117 (Print) 1528-9117 (Linking).

Cattoretti, G., Angelin-Duclos, C., Shaknovich, R., Zhou, H., Wang, D. \& Alobeid, B. (2005), "PRDM1/Blimp-1 is expressed in human B-lymphocytes committed to the plasma cell lineage", J Pathol, Vol. 206 No. 1, 76-86 0022-3417 (Print) 0022-3417 (Linking). 
Chetaille, B., Bertucci, F., Finetti, P., Esterni, B., Stamatoullas, A., Picquenot, J., Copin, M., Morschhauser, F., Casasnovas, O., Petrella, T., Molina, T., Vekhoff, A., Feugier, P., Bouabdallah, R., Birnbaum, D., Olive, D. \& Xerri, L. (2009), "Molecular profiling of classical Hodgkin lymphoma tissues uncovers variations in the tumor microenvironment and correlations with EBV infection and outcome.", Blood, Vol. 113 No. 12, 2765-3775 1528-0020.

Chevalier, P. \& Bernard, J. (Eds) (1932), La maladie de Hodgkin (lymphogranulomatose maligne), Masson, Paris.

Churchill, H. R., Roncador, G., Warnke, R. A. \& Natkunam, Y. (2010), "Programmed death 1 expression in variant immunoarchitectural patterns of nodular lymphocyte predominant Hodgkin lymphoma: comparison with CD57 and lymphomas in the differential diagnosis", Hum Pathol, Vol. 41 No. 12, 1726-1734 1532-8392 (Electronic) 0046-8177 (Linking).

Coffey, F., Alabyev, B. \& Manser, T. (2009), "Initial clonal expansion of germinal center B cells takes place at the perimeter of follicles.", Immunity, Vol. 30 No. 4, 599-609 10974180 .

Cohen, J. (2000), "Epstein-Barr virus infection.", N Engl J Med, Vol. 343 No. 7, 481-492 00284793.

Cronin, M. \& Ross, J. S. (2011), "Comprehensive next-generation cancer genome sequencing in the era of targeted therapy and personalized oncology.", Biomark Med, Vol. 5 No. 3, 293-305 1752-0371.

Crotty, S. (2011), "Follicular helper CD4 T cells (TFH).", Annu Rev Immunol, Vol. 29, 621-663 1545-3278.

Cyster, J. G. (2005), "Chemokines, sphingosine-1-phosphate, and cell migration in secondary lymphoid organs.", Annu Rev Immunol, Vol. 23, 127-159 0732-0582.

Dameshek, W., Weisfuse, L. \& Stein, T. (1949), "Nitrogen mustard therapy in Hodgkin's disease; analysis of 50 consecutive cases", Blood, Vol. 4 No. 4, 338-379 0006-4971 (Print) 0006-4971 (Linking).

Defrance, T., Casamayor-Pallejà, M. \& Krammer, P. H. (2002), "The life and death of a B cell.", Adv Cancer Res, Vol. 86, 195-225 0065-230X.

Devilard, E., Bertucci, F., Trempat, P., Bouabdallah, R., Loriod, B., Giaconia, A., Brousset, P., Granjeaud, S., Nguyen, C., Birnbaum, D., Birg, F., Houlgatte, R. \& Xerri, L. (2002), "Gene expression profiling defines molecular subtypes of classical Hodgkin's disease", Oncogene, Vol. 21 No. 19, 3095-3102 0950-9232 (Print) 0950-9232 (Linking).

DeVita, V. T., Jr. \& Costa, J. (2010), "Toward a personalized treatment of Hodgkin's disease", $N$ Engl J Med, Vol. 362 No. 10, 942-943 1533-4406 (Electronic) 0028-4793 (Linking).

Doerr, J. R., Malone, C. S., Fike, F. M., Gordon, M. S., Soghomonian, S. V., Thomas, R. K., Tao, Q., Murray, P. G., Diehl, V., Teitell, M. A. \& Wall, R. (2005), "Patterned CpG methylation of silenced B cell gene promoters in classical Hodgkin lymphomaderived and primary effusion lymphoma cell lines", J Mol Biol, Vol. 350 No. 4, 631640 0022-2836 (Print) 0022-2836 (Linking).

Dogan, A., Bagdi, E., Munson, P. \& Isaacson, P. G. (2000), "CD10 and BCL-6 expression in paraffin sections of normal lymphoid tissue and B-cell lymphomas.", Am J Surg Pathol, Vol. 24 No. 6, 846-852 0147-5185. 
Dorfman, D. M., Hwang, E. S., Shahsafaei, A. \& Glimcher, L. H. (2005), "T-bet, a T cellassociated transcription factor, is expressed in Hodgkin's lymphoma", Hum Pathol, Vol. 36 No. 1, 10-15 0046-8177 (Print) 0046-8177 (Linking).

Dukers, D. F., van Galen, J. C., Giroth, C., Jansen, P., Sewalt, R. G., Otte, A. P., KluinNelemans, H. C., Meijer, C. J. \& Raaphorst, F. M. (2004), "Unique polycomb gene expression pattern in Hodgkin's lymphoma and Hodgkin's lymphoma-derived cell lines", Am J Pathol, Vol. 164 No. 3, 873-881 0002-9440 (Print) 0002-9440 (Linking).

Eberle, F. C., Mani, H. \& Jaffe, E. S. (2009), "Histopathology of Hodgkin's lymphoma", Cancer J, Vol. 15 No. 2, 129-137 1528-9117 (Print) 1528-9117 (Linking).

Edwards-Bennett, S. M., Jacks, L. M., Moskowitz, C. H., Wu, E. J., Zhang, Z., Noy, A., Portlock, C. S., Straus, D. J., Zelenetz, A. D. \& Yahalom, J. (2010), "Stanford V program for locally extensive and advanced Hodgkin lymphoma: the Memorial Sloan-Kettering Cancer Center experience", Ann Oncol, Vol. 21 No. 3, 574-581 15698041 (Electronic) 0923-7534 (Linking).

Eichenauer, D. A., Bredenfeld, H., Haverkamp, H., Muller, H., Franklin, J., Fuchs, M., Borchmann, P., Muller-Hermelink, H. K., Eich, H. T., Muller, R. P., Diehl, V. \& Engert, A. (2009), "Hodgkin's lymphoma in adolescents treated with adult protocols: a report from the German Hodgkin study group", J Clin Oncol, Vol. 27 No. 36, 6079-6085 1527-7755 (Electronic) 0732-183X (Linking).

Elgueta, R., de Vries, V. C. \& Noelle, R. J. (2010), "The immortality of humoral immunity.", Immunol Rev, Vol. 236, 139-150 1600-065X.

Epstein, M., Barr, Y. \& Achong, B. (1964), "A Second Virus-Carrying Tissue Culture Strain (Eb2) of Lymphoblasts from Burkitt's Lymphoma", Pathol Biol (Paris), Vol. 12, 12331234 0369-8114.

Fadlelmola, F., Zhou, M., de Leeuw, R., Dosanjh, N., Harmer, K., Huntsman, D., Lam, W. \& Banerjee, D. (2008), "Sub-megabase resolution tiling (SMRT) array-based comparative genomic hybridization profiling reveals novel gains and losses of chromosomal regions in Hodgkin Lymphoma and Anaplastic Large Cell Lymphoma cell lines.", Mol Cancer, Vol. 7, 2 1476-4598.

Falini, B., Bigerna, B., Pasqualucci, L., Fizzotti, M., Martelli, M. F., Pileri, S., Pinto, A., Carbone, A., Venturi, S., Pacini, R., Cattoretti, G., Pescarmona, E., Lo Coco, F., Pelicci, P. G., Anagnastopoulos, I., Dalla-Favera, R. \& Flenghi, L. (1996), "Distinctive expression pattern of the BCL-6 protein in nodular lymphocyte predominance Hodgkin's disease", Blood, Vol. 87 No. 2, 465-471 0006-4971 (Print) 0006-4971 (Linking).

Federico, M., Luminari, S., Iannitto, E., Polimeno, G., Marcheselli, L., Montanini, A., La Sala, A., Merli, F., Stelitano, C., Pozzi, S., Scalone, R., Di Renzo, N., Musto, P., Baldini, L., Cervetti, G., Angrilli, F., Mazza, P., Brugiatelli, M. \& Gobbi, P. G. (2009), "ABVD compared with BEACOPP compared with CEC for the initial treatment of patients with advanced Hodgkin's lymphoma: results from the HD2000 Gruppo Italiano per lo Studio dei Linfomi Trial", J Clin Oncol, Vol. 27 No. 5, 805-811 1527-7755 (Electronic) 0732-183X (Linking).

Fox, H. (1926), "Remarks on the presentation of microscopical preparations made from some of the original tissue described by Thomas Hodgkin, 1832.", Ann. Med. Hist. , Vol. 8, 370-374 
Gadue, P. \& Stein, P. L. (2002), "NK T cell precursors exhibit differential cytokine regulation and require Itk for efficient maturation", J Immunol, Vol. 169 No. 5, 2397-2406 $0022-$ 1767 (Print) 0022-1767 (Linking).

Gall, E. \& Mallory, T. (1942), "Malignant Lymphoma: A Clinico-Pathologic Survey of 618 Cases.", Am J Pathol, Vol. 18 No. 3, 381-429 1525-2191.

Gomez-Rodriguez, J., Readinger, J. A., Viorritto, I. C., Mueller, K. L., Houghtling, R. A. \& Schwartzberg, P. L. (2007), "Tec kinases, actin, and cell adhesion", Immunol Rev, Vol. 218, 45-64 0105-2896 (Print) 0105-2896 (Linking).

Good-Jacobson, K. L., Szumilas, C. G., Chen, L., Sharpe, A. H., Tomayko, M. M. \& Shlomchik, M. J. (2010), "PD-1 regulates germinal center B cell survival and the formation and affinity of long-lived plasma cells.", Nat Immunol, Vol. 11 No. 6, 535542 1529-2916.

Goodman, L. S., Wintrobe, M. M. \& et al. (1946), "Nitrogen mustard therapy; use of methylbis (beta-chloroethyl) amine hydrochloride and tris (beta-chloroethyl) amine hydrochloride for Hodgkin's disease, lymphosarcoma, leukemia and certain allied and miscellaneous disorders", J Am Med Assoc, Vol. 132, 126-132 0002-9955 (Print) 0002-9955 (Linking).

Goodnow, C. C., Vinuesa, C. G., Randall, K. L., Mackay, F. \& Brink, R. (2010), "Control systems and decision making for antibody production.", Nat Immunol, Vol. 11 No. 8, 681-688 1529-2916.

Gordon, J., Knox, K. \& Gregory, C. D. (1993), "Regulation of survival in normal and neoplastic B lymphocytes", Leukemia, Vol. 7 Suppl 2, S5-9 0887-6924 (Print) 08876924 (Linking).

Grasis, J. A., Browne, C. D. \& Tsoukas, C. D. (2003), "Inducible T cell tyrosine kinase regulates actin-dependent cytoskeletal events induced by the $\mathrm{T}$ cell antigen receptor", J Immunol, Vol. 170 No. 8, 3971-3976 0022-1767 (Print) 0022-1767 (Linking).

Greenfield, W. (1878), "Specimens illustrative of the pathology of lymphadenoma and leucothemia.", Trans Pathol Soc London, Vol. 29, 272-304

Guzman-Rojas, L., Sims-Mourtada, J. C., Rangel, R. \& Martinez-Valdez, H. (2002), "Life and death within germinal centres: a double-edged sword", Immunology, Vol. 107 No. 2, 167-175 0019-2805 (Print) 0019-2805 (Linking).

Hanrahan, E. M. (1930), "Results of treatment by autogenous gland filtrate in Hodgkin's disease.", Ann Surg, Vol. 92 No. 1, 23-34 0003-4932.

Harris, N. L., Jaffe, E. S., Stein, H., Banks, P. M., Chan, J. K., Cleary, M. L., Delsol, G., De Wolf-Peeters, C., Falini, B., Gatter, K. C. \& et al. (1994), "A revised EuropeanAmerican classification of lymphoid neoplasms: a proposal from the International Lymphoma Study Group", Blood, Vol. 84 No. 5, 1361-1392 0006-4971 (Print) 00064971 (Linking).

Hendrick, A. C. \& Burton, E. F. (1937), "A Case of Hodgkin's Disease Treated with Colloidal Elemental Arsenic", Can Med Assoc J, Vol. 36 No. 5, 519-520 0008-4409 (Print) 00084409 (Linking).

Hennino, A., Bérard, M., Krammer, P. H. \& Defrance, T. (2001), "FLICE-inhibitory protein is a key regulator of germinal center B cell apoptosis.", J Exp Med, Vol. 193 No. 4, 447458 0022-1007. 
Hertel, C. B., Zhou, X. G., Hamilton-Dutoit, S. J. \& Junker, S. (2002), "Loss of B cell identity correlates with loss of B cell-specific transcription factors in Hodgkin/ReedSternberg cells of classical Hodgkin lymphoma", Oncogene, Vol. 21 No. 32, 49084920 0950-9232 (Print) 0950-9232 (Linking).

Hinz, M., Loser, P., Mathas, S., Krappmann, D., Dorken, B. \& Scheidereit, C. (2001), "Constitutive NF-kappaB maintains high expression of a characteristic gene network, including CD40, CD86, and a set of antiapoptotic genes in Hodgkin/Reed-Sternberg cells", Blood, Vol. 97 No. 9, 2798-2807 0006-4971 (Print) 0006-4971 (Linking).

Hodgkin, T. (1832), "On some morbid appearances of the absorbent glands and spleen.", Med. Chirurg. Trans., Vol. 17, 68-114

Hodgkin, T. \& Lister, J. J. (1827), "Notice of some microscopic observations of the blood and animal tissues", Phil. Mag., Vol. ns2, 130-138

Hollowood, K. \& Goodlad, J. R. (1998), "Germinal centre cell kinetics", J Pathol, Vol. 185 No. 3, 229-233 0022-3417 (Print) 0022-3417 (Linking).

Höpken, U. E., Foss, H. D., Meyer, D., Hinz, M., Leder, K., Stein, H. \& Lipp, M. (2002), "Upregulation of the chemokine receptor CCR7 in classical but not in lymphocytepredominant Hodgkin disease correlates with distinct dissemination of neoplastic cells in lymphoid organs.", Blood, Vol. 99 No. 4, 1109-1116 0006-4971.

Howard, J. C., Hunt, S. V. \& Gowans, J. L. (1972), "Identification of marrow-derived and thymus-derived small lymphocytes in the lymphoid tissue and thoracic duct lymph of normal rats.", J Exp Med, Vol. 135 No. 2, 200-219 0022-1007.

Huck, K., Feyen, O., Niehues, T., Ruschendorf, F., Hubner, N., Laws, H. J., Telieps, T., Knapp, S., Wacker, H. H., Meindl, A., Jumaa, H. \& Borkhardt, A. (2009), "Girls homozygous for an IL-2-inducible $\mathrm{T}$ cell kinase mutation that leads to protein deficiency develop fatal EBV-associated lymphoproliferation", J Clin Invest, Vol. 119 No. 5, 1350-1358 1558-8238 (Electronic) 0021-9738 (Linking).

Iyer, A. S. \& August, A. (2008), "The Tec family kinase, IL-2-inducible T cell kinase, differentially controls mast cell responses", J Immunol, Vol. 180 No. 12, 7869-7877 0022-1767 (Print) 0022-1767 (Linking).

Jackson, H. \& Parker, F. (Eds) (1947), Hodgkin's disease and allied disorders., Oxford University Press, New York.

Jaffe, E. S., Harris, N. L., Stein, H. \& Vardiman, J. (Eds) (2001), World Health Organization Classification of Tumours: Pathology and Genetics of Tumours of Haematopoietic and Lymphoid Tissues, IARC Press, 9283224116, Lyon.

Jardin, F., Ruminy, P., Bastard, C. \& Tilly, H. (2007), "The BCL6 proto-oncogene: a leading role during germinal center development and lymphomagenesis", Pathol Biol (Paris), Vol. 55 No. 1, 73-83 0369-8114 (Print) 0369-8114 (Linking).

Jundt, F., Acikgoz, O., Kwon, S. H., Schwarzer, R., Anagnostopoulos, I., Wiesner, B., Mathas, S., Hummel, M., Stein, H., Reichardt, H. M. \& Dorken, B. (2008), "Aberrant expression of Notch1 interferes with the B-lymphoid phenotype of neoplastic B cells in classical Hodgkin lymphoma", Leukemia, Vol. 22 No. 8, 1587-1594 1476-5551 (Electronic) 0887-6924 (Linking).

Jundt, F., Kley, K., Anagnostopoulos, I., Schulze Probsting, K., Greiner, A., Mathas, S., Scheidereit, C., Wirth, T., Stein, H. \& Dorken, B. (2002), "Loss of PU.1 expression is associated with defective immunoglobulin transcription in Hodgkin and Reed- 
Sternberg cells of classical Hodgkin disease", Blood, Vol. 99 No. 8, 3060-3062 00064971 (Print) 0006-4971 (Linking).

Kapatai, G. \& Murray, P. (2007), "Contribution of the Epstein Barr virus to the molecular pathogenesis of Hodgkin lymphoma.", J Clin Pathol, Vol. 60 No. 12, 1342-1349 14724146.

Kashkar, H., Deggerich, A., Seeger, J. M., Yazdanpanah, B., Wiegmann, K., Haubert, D., Pongratz, C. \& Kronke, M. (2007), "NF-kappaB-independent down-regulation of XIAP by bortezomib sensitizes HL B cells against cytotoxic drugs", Blood, Vol. 109 No. 9, 3982-3988 0006-4971 (Print) 0006-4971 (Linking).

Kim, J. R., Lim, H. W., Kang, S. G., Hillsamer, P. \& Kim, C. H. (2005), "Human CD57+ germinal center-T cells are the major helpers for GC-B cells and induce class switch recombination.", BMC Immunol, Vol. 6, 3 1471-2172.

Kis, L. L., Nagy, N., Klein, G. \& Klein, E. (2003), "Expression of SH2D1A in five classical Hodgkin's disease-derived cell lines", Int J Cancer, Vol. 104 No. 5, 658-661 0020-7136 (Print) 0020-7136 (Linking).

Kishimoto, T. (2010), "IL-6: from its discovery to clinical applications.", Int Immunol, Vol. 22 No. 5, 347-352 1460-2377.

Kosco-Vilbois, M. H. (2003), "Are follicular dendritic cells really good for nothing?", Nat Rev Immunol, Vol. 3 No. 9, 764-769 1474-1733 (Print) 1474-1733 (Linking).

Kuppers, R. (2009), "The biology of Hodgkin's lymphoma", Nat Rev Cancer, Vol. 9 No. 1, 1527 1474-1768 (Electronic) 1474-175X (Linking).

Küppers, R. (2009), "Molecular biology of Hodgkin lymphoma.", Hematology Am Soc Hematol Educ Program, 491-496 1520-4383.

Kuppers, R., Schwering, I., Brauninger, A., Rajewsky, K. \& Hansmann, M. L. (2002), "Biology of Hodgkin's lymphoma", Ann Oncol, Vol. 13 Suppl 1, 11-18 0923-7534 (Print) 09237534 (Linking).

Lamprecht, B., Kreher, S., Anagnostopoulos, I., Johrens, K., Monteleone, G., Jundt, F., Stein, H., Janz, M., Dorken, B. \& Mathas, S. (2008), "Aberrant expression of the Th2 cytokine IL-21 in Hodgkin lymphoma cells regulates STAT3 signaling and attracts Treg cells via regulation of MIP-3alpha", Blood, Vol. 112 No. 8, 3339-3347 1528-0020 (Electronic) 0006-4971 (Linking).

Langhans, T. (1872), "Das maligne Lymphosarkum Pseudoleukamie", Virchows Pathol Anat, Vol. 54, 509-536

Leslie, E., Deeley, R. \& Cole, S. (2001), "Toxicological relevance of the multidrug resistance protein 1, MRP1 (ABCC1) and related transporters.", Toxicology, Vol. 167 No. 1, 3-23 0300-483X.

Liso, A., Capello, D., Marafioti, T., Tiacci, E., Cerri, M., Distler, V., Paulli, M., Carbone, A., Delsol, G., Campo, E., Pileri, S., Pasqualucci, L., Gaidano, G. \& Falini, B. (2006), "Aberrant somatic hypermutation in tumor cells of nodular-lymphocytepredominant and classic Hodgkin lymphoma", Blood, Vol. 108 No. 3, 1013-1020 0006-4971 (Print) 0006-4971 (Linking).

Loughran, S. T., Campion, E. M., D'Souza, B. N., Smith, S. M., Vrzalikova, K., Wen, K., Murray, P. G. \& Walls, D. (2011), "Bfl-1 is a crucial pro-survival nuclear factorkappaB target gene in Hodgkin/Reed-Sternberg cells", Int J Cancer 1097-0215 (Electronic) 0020-7136 (Linking). 
Lukes, R., Craver, L., Hal, 1. T., Rappaport, H. \& Ruben, P. (1966), "Report of the Nomenclature Committee", Cancer Res, Vol. 26, 1311

Lukes, R. J., Butler, J. \& Hicks, E. B. (1966), "[The prognosis of Hodgkin's disease according to the histologic type and the clinical stage. Role of the reactions of the host]", Nouv Rev Fr Hematol, Vol. 6 No. 1, 15-22 0029-4810 (Print) 0029-4810 (Linking).

Lukes, R. J. \& Butler, J. J. (1966), "The pathology and nomenclature of Hodgkin's disease", Cancer Res, Vol. 26 No. 6, 1063-1083 0008-5472 (Print) 0008-5472 (Linking).

Malpighi, M. (1666), "De Viscerum Structura Exercitatio Anatomica.", in. J. Montij, Bononiae, pp. 125-156.

Mani, H. \& Jaffe, E. S. (2009), "Hodgkin lymphoma: an update on its biology with new insights into classification", Clin Lymphoma Myeloma, Vol. 9 No. 3, 206-216 1938-0712 (Electronic) 1557-9190 (Linking).

Marafioti, T., Hummel, M., Foss, H. D., Laumen, H., Korbjuhn, P., Anagnostopoulos, I., Lammert, H., Demel, G., Theil, J., Wirth, T. \& Stein, H. (2000), "Hodgkin and reedsternberg cells represent an expansion of a single clone originating from a germinal center B-cell with functional immunoglobulin gene rearrangements but defective immunoglobulin transcription", Blood, Vol. 95 No. 4, 1443-1450 0006-4971 (Print) 0006-4971 (Linking).

Masir, N., Marafioti, T., Jones, M., Natkunam, Y., Rudiger, T., Hansmann, M. L. \& Mason, D. Y. (2006), "Loss of CD19 expression in B-cell neoplasms", Histopathology, Vol. 48 No. 3, 239-246 0309-0167 (Print) 0309-0167 (Linking).

Mathas, S. (2007), "The pathogenesis of classical Hodgkin's lymphoma: a model for B-cell plasticity.", Hematol Oncol Clin North Am, Vol. 21 No. 5, 787-804 0889-8588.

Mathas, S., Janz, M., Hummel, F., Hummel, M., Wollert-Wulf, B., Lusatis, S., Anagnostopoulos, I., Lietz, A., Sigvardsson, M., Jundt, F., Johrens, K., Bommert, K., Stein, H. \& Dorken, B. (2006), "Intrinsic inhibition of transcription factor E2A by HLH proteins ABF-1 and Id2 mediates reprogramming of neoplastic B cells in Hodgkin lymphoma", Nat Immunol, Vol. 7 No. 2, 207-215 1529-2908 (Print) 15292908 (Linking).

Mathas, S., Lietz, A., Anagnostopoulos, I., Hummel, F., Wiesner, B., Janz, M., Jundt, F., Hirsch, B., Jöhrens-Leder, K., Vornlocher, H. P., Bommert, K., Stein, H. \& Dörken, B. (2004), "c-FLIP mediates resistance of Hodgkin/Reed-Sternberg cells to death receptor-induced apoptosis.", J Exp Med, Vol. 199 No. 8, 1041-1052 0022-1007.

Mathas, S., Lietz, A., Janz, M., Hinz, M., Jundt, F., Scheidereit, C., Bommert, K. \& Dorken, B. (2003), "Inhibition of NF-kappaB essentially contributes to arsenic-induced apoptosis", Blood, Vol. 102 No. 3, 1028-1034 0006-4971 (Print) 0006-4971 (Linking).

Mendler, J. H., Kelly, J., Voci, S., Marquis, D., Rich, L., Rossi, R. M., Bernstein, S. H., Jordan, C. T., Liesveld, J., Fisher, R. I. \& Friedberg, J. W. (2008), "Bortezomib and gemcitabine in relapsed or refractory Hodgkin's lymphoma", Ann Oncol, Vol. 19 No. 10, 1759-1764 1569-8041 (Electronic) 0923-7534 (Linking).

Montes-Moreno, S., Roncador, G., Maestre, L., Martinez, N., Sanchez-Verde, L., Camacho, F. I., Cannata, J., Martinez-Torrecuadrada, J. L., Shen, Y., Chan, W. C. \& Piris, M. A. (2008), "Gcet1 (centerin), a highly restricted marker for a subset of germinal centerderived lymphomas", Blood, Vol. 111 No. 1, 351-358 0006-4971 (Print) 0006-4971 (Linking). 
Morin, R. D., Johnson, N. A., Severson, T. M., Mungall, A. J., An, J., Goya, R., Paul, J. E., Boyle, M., Woolcock, B. W., Kuchenbauer, F., Yap, D., Humphries, R. K., Griffith, O. L., Shah, S., Zhu, H., Kimbara, M., Shashkin, P., Charlot, J. F., Tcherpakov, M., Corbett, R., Tam, A., Varhol, R., Smailus, D., Moksa, M., Zhao, Y., Delaney, A., Qian, H., Birol, I., Schein, J., Moore, R., Holt, R., Horsman, D. E., Connors, J. M., Jones, S., Aparicio, S., Hirst, M., Gascoyne, R. D. \& Marra, M. A. (2010), "Somatic mutations altering EZH2 (Tyr641) in follicular and diffuse large B-cell lymphomas of germinal-center origin.", Nat Genet, Vol. 42 No. 2, 181-185 1546-1718.

Mottok, A., Hansmann, M. L. \& Bräuninger, A. (2005), "Activation induced cytidine deaminase expression in lymphocyte predominant Hodgkin lymphoma.", J Clin Pathol, Vol. 58 No. 9, 1002-1004 0021-9746.

Murphy, D., Parker, J., Zhou, M., Fadlelmola, F., Steidl, C., Karsan, A., Gascoyne, R., Chen, H. \& Banerjee, D. (2010), "Constitutively overexpressed $21 \mathrm{kDa}$ protein in Hodgkin lymphoma and aggressive non-Hodgkin lymphomas identified as cytochrome B5b (CYB5B).", Mol Cancer, Vol. 9, 14 1476-4598.

Nagel, S., Scherr, M., Quentmeier, H., Kaufmann, M., Zaborski, M., Drexler, H. G. \& MacLeod, R. A. (2005), "HLXB9 activates IL6 in Hodgkin lymphoma cell lines and is regulated by PI3K signalling involving E2F3.", Leukemia, Vol. 19 No. 5, 841-846 0887-6924.

Nam-Cha, S. H., Montes-Moreno, S., Salcedo, M. T., Sanjuan, J., Garcia, J. F. \& Piris, M. A. (2009), "Lymphocyte-rich classical Hodgkin's lymphoma: distinctive tumor and microenvironment markers", Mod Pathol, Vol. 22 No. 8, 1006-1015 1530-0285 (Electronic) 0893-3952 (Linking).

Nichols, K. E., Harkin, D. P., Levitz, S., Krainer, M., Kolquist, K. A., Genovese, C., Bernard, A., Ferguson, M., Zuo, L., Snyder, E., Buckler, A. J., Wise, C., Ashley, J., Lovett, M., Valentine, M. B., Look, A. T., Gerald, W., Housman, D. E. \& Haber, D. A. (1998), "Inactivating mutations in an $\mathrm{SH} 2$ domain-encoding gene in X-linked lymphoproliferative syndrome", Proc Natl Acad Sci U S A, Vol. 95 No. 23, 1376513770 0027-8424 (Print) 0027-8424 (Linking).

Norde, W. J., Maas, F., Hobo, W., Korman, A., Quigley, M., Kester, M. G., Hebeda, K., Falkenburg, J. H., Schaap, N., de Witte, T. M., van der Voort, R. \& Dolstra, H. (2011), "PD-1/PD-L1 Interactions Contribute to Functional T-Cell Impairment in Patients Who Relapse with Cancer After Allogeneic Stem Cell Transplantation", Cancer Res, Vol. 71 No. 15, 5111-5122 1538-7445 (Electronic) 0008-5472 (Linking).

Nutt, S. L. \& Tarlinton, D. M. (2011), "Germinal center B and follicular helper T cells: siblings, cousins or just good friends?", Nat Immunol, Vol. 12 No. 6, 472-477 15292916.

Oflazoglu, E., Kissler, K. M., Sievers, E. L., Grewal, I. S. \& Gerber, H. P. (2008), "Combination of the anti-CD30-auristatin-E antibody-drug conjugate (SGN-35) with chemotherapy improves antitumour activity in Hodgkin lymphoma", Br J Haematol, Vol. 142 No. 1, 69-73 1365-2141 (Electronic) 0007-1048 (Linking).

Okada, T. \& Cyster, J. G. (2006), "B cell migration and interactions in the early phase of antibody responses.", Curr Opin Immunol, Vol. 18 No. 3, 278-285 0952-7915.

Oracki, S. A., Walker, J. A., Hibbs, M. L., Corcoran, L. M. \& Tarlinton, D. M. (2010), "Plasma cell development and survival.", Immunol Rev, Vol. 237 No. 1, 140-159 1600-065X. 
Park, C. S. \& Choi, Y. S. (2005), "How do follicular dendritic cells interact intimately with B cells in the germinal centre?", Immunology, Vol. 114 No. 1, 2-10 0019-2805 (Print) 0019-2805 (Linking).

Peters, M. V. (1960), "The place of irradiation in the control of Hodgkin's disease", Proc Natl Cancer Conf, Vol. 4, 571-584 0077-3670 (Print) 0077-3670 (Linking).

Peters, M. V. (1965), "Current Concepts in Cancer. 2. Hodgkin's Disease. Radiation Therapy", JAMA, Vol. 191, 28-29 0098-7484 (Print) 0098-7484 (Linking).

Peters, M. V. (1966), "Prophylactic treatment of adjacent areas in Hodgkin's disease", Cancer Res, Vol. 26 No. 6, 1232-1243 0008-5472 (Print) 0008-5472 (Linking).

Peters, M. V. \& Middlemiss, K. C. (1958), "A study of Hodgkin's disease treated by irradiation", Am J Roentgenol Radium Ther Nucl Med, Vol. 79 No. 1, 114-121 00029580 (Print) 0002-9580 (Linking).

Phan, R. T. \& Dalla-Favera, R. (2004), "The BCL6 proto-oncogene suppresses p53 expression in germinal-centre B cells", Nature, Vol. 432 No. 7017, 635-639 1476-4687 (Electronic) 0028-0836 (Linking).

Poston, R. N. (1999), "A new look at the original cases of Hodgkin's disease", Cancer Treat Rev, Vol. 25 No. 3, 151-155 0305-7372 (Print) 0305-7372 (Linking).

Purtilo, D. T., Cassel, C. K., Yang, J. P. \& Harper, R. (1975), "X-linked recessive progressive combined variable immunodeficiency (Duncan's disease)", Lancet, Vol. 1 No. 7913, 935-940 0140-6736 (Print) 0140-6736 (Linking).

Qi, Q., Xia, M., Bai, Y., Yu, S., Cantorna, M. \& August, A. (2011), "Interleukin-2-inducible T cell kinase (Itk) network edge dependence for the maturation of iNKT cell", J Biol Chem, Vol. 286 No. 1, 138-146 1083-351X (Electronic) 0021-9258 (Linking).

Raaphorst, F. M., van Kemenade, F. J., Blokzijl, T., Fieret, E., Hamer, K. M., Satijn, D. P., Otte, A. P. \& Meijer, C. J. (2000), "Coexpression of BMI-1 and EZH2 polycomb group genes in Reed-Sternberg cells of Hodgkin's disease", Am J Pathol, Vol. 157 No. 3, 709-715 0002-9440 (Print) 0002-9440 (Linking).

Rasheed, A. U., Rahn, H. P., Sallusto, F., Lipp, M. \& Müller, G. (2006), "Follicular B helper T cell activity is confined to CXCR5(hi)ICOS(hi) CD4 T cells and is independent of CD57 expression.", Eur J Immunol, Vol. 36 No. 7, 1892-1903 0014-2980.

Reed, D. (1902), "On the pathological changes in Hodgkin's disease with especial reference to its relation to tuberculosis.", Johns Hopkins Hosp Rep, Vol. 10, 133-136

Rezaei, N., Hedayat, M., Aghamohammadi, A. \& Nichols, K. E. (2011), "Primary immunodeficiency diseases associated with increased susceptibility to viral infections and malignancies", J Allergy Clin Immunol, Vol. 127 No. 6, 1329-1341 e1322; quiz 1342-1323 1097-6825 (Electronic) 0091-6749 (Linking).

Rezaei, N., Mahmoudi, E., Aghamohammadi, A., Das, R. \& Nichols, K. E. (2011), "X-linked lymphoproliferative syndrome: a genetic condition typified by the triad of infection, immunodeficiency and lymphoma", Br J Haematol, Vol. 152 No. 1, 13-30 1365-2141 (Electronic) 0007-1048 (Linking).

Rosenberg, M., Mao, Q., Holzenburg, A., Ford, R., Deeley, R. \& Cole, S. (2001), "The structure of the multidrug resistance protein 1 (MRP1/ABCC1). crystallization and single-particle analysis.", J Biol Chem, Vol. 276 No. 19, 16076-16082 0021-9258.

Saini, K. S., Azim, H. A., Cocorocchio, E., Vanazzi, A., Saini, M. L., Raviele, P. R., Pruneri, G. \& Peccatori, F. A. (2011), "Rituximab in Hodgkin lymphoma: is the target always a hit?", Cancer Treat Rev, Vol. 37 No. 5, 385-390 1532-1967. 
Sanchez-Aguilera, A., Montalban, C., de la Cueva, P., Sanchez-Verde, L., Morente, M. M., Garcia-Cosio, M., Garcia-Larana, J., Bellas, C., Provencio, M., Romagosa, V., de Sevilla, A. F., Menarguez, J., Sabin, P., Mestre, M. J., Mendez, M., Fresno, M. F., Nicolas, C., Piris, M. A. \& Garcia, J. F. (2006), "Tumor microenvironment and mitotic checkpoint are key factors in the outcome of classic Hodgkin lymphoma", Blood, Vol. 108 No. 2, 662-668 0006-4971 (Print) 0006-4971 (Linking).

Schenka, A. A., Muller, S., Fournie, J. J., Capila, F., Vassallo, J., Delsol, G., Valitutti, S. \& Brousset, P. (2005), "CD4+ T cells downregulate Bcl-2 in germinal centers", J Clin Immunol, Vol. 25 No. 3, 224-229 0271-9142 (Print) 0271-9142 (Linking).

Schmitz, R., Stanelle, J., Hansmann, M. L. \& Kuppers, R. (2009), "Pathogenesis of classical and lymphocyte-predominant Hodgkin lymphoma", Annu Rev Pathol, Vol. 4, 151174 1553-4014 (Electronic).

Schwering, I., Brauninger, A., Klein, U., Jungnickel, B., Tinguely, M., Diehl, V., Hansmann, M. L., Dalla-Favera, R., Rajewsky, K. \& Kuppers, R. (2003), "Loss of the B-lineagespecific gene expression program in Hodgkin and Reed-Sternberg cells of Hodgkin lymphoma", Blood, Vol. 101 No. 4, 1505-1512 0006-4971 (Print) 0006-4971 (Linking).

Sears, D. A. (1988), "History of the treatment of chronic myelocytic leukemia", Am J Med Sci, Vol. 296 No. 2, 85-86 0002-9629 (Print) 0002-9629 (Linking).

Seemayer, T. A., Gross, T. G., Egeler, R. M., Pirruccello, S. J., Davis, J. R., Kelly, C. M., Okano, M., Lanyi, A. \& Sumegi, J. (1995), "X-linked lymphoproliferative disease: twenty-five years after the discovery", Pediatr Res, Vol. 38 No. 4, 471-478 0031-3998 (Print) 0031-3998 (Linking).

Seif, G. S. \& Spriggs, A. I. (1967), "Chromosome changes in Hodgkin's disease", J Natl Cancer Inst, Vol. 39 No. 3, 557-570 0027-8874 (Print) 0027-8874 (Linking).

Seitz, V., Hummel, M., Marafioti, T., Anagnostopoulos, I., Assaf, C. \& Stein, H. (2000), "Detection of clonal T-cell receptor gamma-chain gene rearrangements in ReedSternberg cells of classic Hodgkin disease.", Blood, Vol. 95 No. 10, 3020-3024 00064971.

Shafer, J. A., Cruz, C. R., Leen, A. M., Ku, S., Lu, A., Rousseau, A., Heslop, H. E., Rooney, C. M., Bollard, C. M. \& Foster, A. E. (2010), "Antigen-specific cytotoxic T lymphocytes can target chemoresistant side-population tumor cells in Hodgkin lymphoma", Leuk Lymphoma, Vol. 51 No. 5, 870-880 1029-2403 (Electronic) 1026-8022 (Linking).

Siepmann, K., Skok, J., van Essen, D., Harnett, M. \& Gray, D. (2001), "Rewiring of CD40 is necessary for delivery of rescue signals to $\mathrm{B}$ cells in germinal centres and subsequent entry into the memory pool", Immunology, Vol. 102 No. 3, 263-272 00192805 (Print) 0019-2805 (Linking).

Smetana, H. F. \& Cohen, B. M. (1956), "Mortality in relation to histologic type in Hodgkin's disease", Blood, Vol. 11 No. 3, 211-224 0006-4971 (Print) 0006-4971 (Linking).

Spender, L. C., O'Brien, D. I., Simpson, D., Dutt, D., Gregory, C. D., Allday, M. J., Clark, L. J. \& Inman, G. J. (2009), "TGF-beta induces apoptosis in human B cells by transcriptional regulation of BIK and BCL-XL", Cell Death Differ, Vol. 16 No. 4, 593602 1476-5403 (Electronic) 1350-9047 (Linking).

Staege, M. S., Banning-Eichenseer, U., Weissflog, G., Volkmer, I., Burdach, S., Richter, G., Mauz-Korholz, C., Foll, J. \& Korholz, D. (2008), "Gene expression profiles of Hodgkin's lymphoma cell lines with different sensitivity to cytotoxic drugs", Exp Hematol, Vol. 36 No. 7, 886-896 0301-472X (Print) 0301-472X (Linking). 
Steidl, C., Lee, T., Shah, S. P., Farinha, P., Han, G., Nayar, T., Delaney, A., Jones, S. J., Iqbal, J., Weisenburger, D. D., Bast, M. A., Rosenwald, A., Muller-Hermelink, H. K., Rimsza, L. M., Campo, E., Delabie, J., Braziel, R. M., Cook, J. R., Tubbs, R. R., Jaffe, E. S., Lenz, G., Connors, J. M., Staudt, L. M., Chan, W. C. \& Gascoyne, R. D. (2010), "Tumor-associated macrophages and survival in classic Hodgkin's lymphoma", $N$ Engl J Med, Vol. 362 No. 10, 875-885 1533-4406 (Electronic) 0028-4793 (Linking).

Steidl, C., Shah, S. P., Woolcock, B. W., Rui, L., Kawahara, M., Farinha, P., Johnson, N. A., Zhao, Y., Telenius, A., Neriah, S. B., McPherson, A., Meissner, B., Okoye, U. C., Diepstra, A., van den Berg, A., Sun, M., Leung, G., Jones, S. J., Connors, J. M., Huntsman, D. G., Savage, K. J., Rimsza, L. M., Horsman, D. E., Staudt, L. M., Steidl, U., Marra, M. A. \& Gascoyne, R. D. (2011), "MHC class II transactivator CIITA is a recurrent gene fusion partner in lymphoid cancers.", Nature, Vol. 471 No. 7338, 377381 1476-4687.

Steidl, C., Telenius, A., Shah, S. P., Farinha, P., Barclay, L., Boyle, M., Connors, J. M., Horsman, D. E. \& Gascoyne, R. D. (2010), "Genome-wide copy number analysis of Hodgkin Reed-Sternberg cells identifies recurrent imbalances with correlations to treatment outcome", Blood 1528-0020 (Electronic) 0006-4971 (Linking).

Stein, H., Marafioti, T., Foss, H. D., Laumen, H., Hummel, M., Anagnostopoulos, I., Wirth, T., Demel, G. \& Falini, B. (2001), "Down-regulation of BOB.1/OBF.1 and Oct2 in classical Hodgkin disease but not in lymphocyte predominant Hodgkin disease correlates with immunoglobulin transcription.", Blood, Vol. 97 No. 2, 496-501 00064971.

Stepensky, P., Weintraub, M., Yanir, A., Revel-Vilk, S., Krux, F., Huck, K., Linka, R. M., Shaag, A., Elpeleg, O., Borkhardt, A. \& Resnick, I. B. (2011), "IL-2-inducible T-cell kinase deficiency: clinical presentation and therapeutic approach", Haematologica, Vol. 96 No. 3, 472-476 1592-8721 (Electronic) 0390-6078 (Linking).

Sternberg, C. (1898), "Ueber eine Eigenartige unter dem Bilde der Pseudoleukaemie verlaufende Tuberculosis des lymphatischen Apparates.", Ztschr Heilk, Vol. 19, 2130

Swerdlow, S. H., Campo, E., Harris, N. L., Jaffe, E. S., Pileri, S. A., Stein, H., Thiele, J. \& Vardiman, J. W. (Eds) (2008), WHO Classification of Tumours of Haematopoietic and Lymphoid Tissues., IARC Press, 9283224310, Lyon, France.

Tarlinton, D. M. \& Smith, K. G. (2000), "Dissecting affinity maturation: a model explaining selection of antibody-forming cells and memory B cells in the germinal centre", Immunol Today, Vol. 21 No. 9, 436-441 0167-5699 (Print) 0167-5699 (Linking).

Tedoldi, S., Mottok, A., Ying, J., Paterson, J. C., Cui, Y., Facchetti, F., van Krieken, J. H., Ponzoni, M., Ozkal, S., Masir, N., Natkunam, Y., Pileri, S., Hansmann, M. L., Mason, D., Tao, Q. \& Marafioti, T. (2007), "Selective loss of B-cell phenotype in lymphocyte predominant Hodgkin lymphoma", J Pathol, Vol. 213 No. 4, 429-440 0022-3417 (Print) 0022-3417 (Linking).

Tesch, H., Feller, A. C., Jücker, M., Klein, S., Merz, H. \& Diehl, V. (1992), "Activation of cytokines in Hodgkin's disease.", Ann Oncol, Vol. 3 Suppl 4, 13-16 0923-7534.

Thomas, R., Kallenborn, A., Wickenhauser, C., Schultze, J., Draube, A., Vockerodt, M., Re, D., Diehl, V. \& Wolf, J. (2002), "Constitutive expression of c-FLIP in Hodgkin and Reed-Sternberg cells.", Am J Pathol, Vol. 160 No. 4, 1521-1528 0002-9440. 
Uherova, P., Olson, S., Thompson, M. A., Juskevicius, R. \& Hamilton, K. S. (2004), "Expression of c-FLIP in classic and nodular lymphocyte-predominant Hodgkin lymphoma.", Appl Immunohistochem Mol Morphol, Vol. 12 No. 2, 105-110 1541-2016.

Uluç, K., Kujoth, G. C. \& Başkaya, M. K. (2009), "Operating microscopes: past, present, and future.", Neurosurg Focus, Vol. 27 No. 3, E4 1092-0684.

Ushmorov, A., Leithauser, F., Sakk, O., Weinhausel, A., Popov, S. W., Moller, P. \& Wirth, T. (2006), "Epigenetic processes play a major role in B-cell-specific gene silencing in classical Hodgkin lymphoma", Blood, Vol. 107 No. 6, 2493-2500 0006-4971 (Print) 0006-4971 (Linking).

Vener, C., Guffanti, A., Pomati, M., Colombi, M., Alietti, A., La Targia, M. L., BamontiCatena, F. \& Baldini, L. (2000), "Soluble cytokine levels correlate with the activity and clinical stage of Hodgkin's disease at diagnosis.", Leuk Lymphoma, Vol. 37 No. 34, 333-339 1042-8194.

Vikstrom, I. \& Tarlinton, D. M. (2011), "B cell memory and the role of apoptosis in its formation.", Mol Immunol, Vol. 48 No. 11, 1301-1306 1872-9142.

Vinuesa, C. G., Linterman, M. A., Goodnow, C. C. \& Randall, K. L. (2010), "T cells and follicular dendritic cells in germinal center B-cell formation and selection.", Immunol Rev, Vol. 237 No. 1, 72-89 1600-065X.

Wallhauser, A. \& Whitehead, J. M. (1928), "IMMUNOLOGICAL METHOD IN HODGKIN'S DISEASE: A PRELIMINARY REPORT", Amcrican Journd ol' Surgery., Vol. v No. September, 229-233

Waxman, S. \& Anderson, K. C. (2001), "History of the development of arsenic derivatives in cancer therapy", Oncologist, Vol. 6 Suppl 2, 3-10 1083-7159 (Print) 1083-7159 (Linking).

Wilks, S. (1856), "Cases of lardaceous disease and some allied affections. With remarks. ", Guy's Hosp. Rep. , Vol. 2, 103-132

Wilks, S. (1859), "Diseases, etc., of the ductless glands. I. The spleen.", Trans. Pathol. Soc.London Vol. 10, 259-263

Wilks, S. (1865), "Cases of enlargement of the lymphatic glands and spleen, (or, Hodgkin's disease), with remarks. ", Guy's Hosp. Rep. , Vol. 11, 56-67

Yamamoto, R., Nishikori, M., Kitawaki, T., Sakai, T., Hishizawa, M., Tashima, M., Kondo, T., Ohmori, K., Kurata, M., Hayashi, T. \& Uchiyama, T. (2008), "PD-1-PD-1 ligand interaction contributes to immunosuppressive microenvironment of Hodgkin lymphoma", Blood, Vol. 111 No. 6, 3220-3224 0006-4971 (Print) 0006-4971 (Linking).

Younes, A. (2009), "Novel treatment strategies for patients with relapsed classical Hodgkin lymphoma.", Hematology Am Soc Hematol Educ Program, 507-519 1520-4383.

Younes, A., Romaguera, J., Hagemeister, F., McLaughlin, P., Rodriguez, M. A., Fiumara, P., Goy, A., Jeha, S., Manning, J. T., Jr., Jones, D., Abruzzo, L. V. \& Medeiros, L. J. (2003), "A pilot study of rituximab in patients with recurrent, classic Hodgkin disease", Cancer, Vol. 98 No. 2, 310-314 0008-543X (Print) 0008-543X (Linking).

Yu, D., Rao, S., Tsai, L. M., Lee, S. K., He, Y., Sutcliffe, E. L., Srivastava, M., Linterman, M., Zheng, L., Simpson, N., Ellyard, J. I., Parish, I. A., Ma, C. S., Li, Q. J., Parish, C. R., Mackay, C. R. \& Vinuesa, C. G. (2009), "The transcriptional repressor Bcl-6 directs T follicular helper cell lineage commitment.", Immunity, Vol. 31 No. 3, 457-468 10974180 . 
Zhang, Q. P., Xie, L. K., Zhang, L. J. \& Tan, J. Q. (2005), "Apoptosis in human germinal centre B cells by means of CC chemokine receptor 3 expression induced by interleukin-2 and interleukin-4", Chin Med J (Engl), Vol. 118 No. 8, 665-670 03666999 (Print) 0366-6999 (Linking).

Zhou, M., Fadlelmola, F. M., Cohn, J. B., Skinnider, B., Gascoyne, R. D. \& Banerjee, D. (2008), "Constitutive overexpression of a novel $21 \mathrm{kDa}$ protein by Hodgkin lymphoma and aggressive non-Hodgkin lymphomas.", Mol Cancer, Vol. 7, 12 1476-4598. 


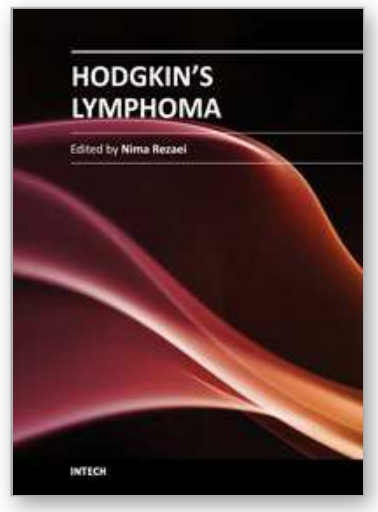

\author{
Hodgkin's Lymphoma \\ Edited by Dr. Nima Rezaei
}

ISBN 978-953-51-0402-5

Hard cover, 272 pages

Publisher InTech

Published online 23, March, 2012

Published in print edition March, 2012

Hodgkin's Lymphoma is the book consisting of 11 chapters: Recent insights into the biology of Hodgkin's lymphoma, including historical aspects, epidemiology, pathophysiology, genetic defects, and prognostic indicators are explained in the intro chapters. After a translational chapter from tumor microenvironment to immunotherapeutic approach, treatment of early stage, advanced, and refractory Hodgkin's lymphoma are explained in the following chapters. MALT lymphoma and adverse effects of chemotherapy and radiotherapy in the affected patients are discussed in the subsequent chapters, while the final chapter is focused on survivorship in Hodgkin's lymphoma. The book is intended to present recent advances in the pathophysiology of Hodgkin's lymphoma as well as practical approach to diagnosis and management in clinical practice, which is hoped to be welcomed by the physicians, who wish to learn more about Hodgkin's lymphoma.

\title{
How to reference
}

In order to correctly reference this scholarly work, feel free to copy and paste the following:

Diponkar Banerjee (2012). Recent Insights into the Biology of Hodgkin's Lymphoma, Hodgkin's Lymphoma, Dr. Nima Rezaei (Ed.), ISBN: 978-953-51-0402-5, InTech, Available from:

http://www.intechopen.com/books/hodgkin-s-lymphoma/recent-insights-into-the-biology-of-hodgkin

\section{INTECH}

open science | open minds

\section{InTech Europe}

University Campus STeP Ri

Slavka Krautzeka 83/A

51000 Rijeka, Croatia

Phone: +385 (51) 770447

Fax: +385 (51) 686166

www.intechopen.com

\section{InTech China}

Unit 405, Office Block, Hotel Equatorial Shanghai

No.65, Yan An Road (West), Shanghai, 200040, China

中国上海市延安西路65号上海国际贵都大饭店办公楼 405 单元

Phone: +86-21-62489820

Fax: +86-21-62489821 
(C) 2012 The Author(s). Licensee IntechOpen. This is an open access article distributed under the terms of the Creative Commons Attribution 3.0 License, which permits unrestricted use, distribution, and reproduction in any medium, provided the original work is properly cited. 